\title{
THE KYLMÄKOSKI NICKEL-COPPER DEPOSIT IN SOUTHWESTERN FINLAND
}

\author{
HEIKKI PAPUNEN
}

\begin{abstract}
PAPUNEN, HEIKKI 1980: The Kylmäkoski nickel-copper deposit in south-western Finland Bull. Geol. Soc. Finland, 52, 129-145.

The Kylmäkoski sulfide Ni-Cu deposit is located in southwestern Finland in the WNW trending Pori-Kylmäkoski nickel belt which contains several other sulfide $\mathrm{Ni}-\mathrm{Cu}$ occurrences besides Kylmäkoski. The original reserves of the Kylmäkoski ore were ca. 0.5 million tons of ore assaying $0.48 \% \mathrm{Cu}$ and $0.55 \% \mathrm{Ni}$. The ore was exploited in 1971-1974. The wedge-shaped host ultramafic body with sinuous contacts against the wall-rock mica gneiss was almost wholly mineralized. The body was bordered in the north by an intersecting quartz diorite. The main rock types are peridotites, pyroxenite and hornblendite, and the differentiation is supposed to be caused by wall-rock contamination. The peridotites include rare orbicular and nodular varieties whose peculiar texture is due to the rapid crystallization of skeletal olivine. The ultramafic body has undergone regional metamorphism and recrystallization. Sulfides exist either as primary disseminated grains or accumulations brought about by gravitative settling or as massive and breccia ores generated by later tectonic events. A nickel-arsenide mineral assemblage abounds as massive veins related to the intersecting quartz diorite dikes. Platinum-group elements are concentrated in the nickelarsenide mineralization. The lead-lead modal age of the body is 1856 $\mathrm{Ma}$. The emplacement of the ultramafite is suggested to predate folding and regional metamorphism.

Heikki Papunen, Institute of Geology and Mineralogy, University of Turku, SF-20500 Turku 50, Finland.
\end{abstract}

\section{Introduction}

At the beginning of the $1960 \mathrm{~s}$ the belt trending ESE from Pori, a town in western Finland, became known for its abundant new indications of Ni-Cu occurrences. The indications were mainly ore samples sent to exploration companies by local people; an exploration method that has been succesfully applied in Finland since the 1930s. The first hints of the Kylmäkoski ore were received in 1962, when two schoolboys found a big glacial boulder of $\mathrm{Ni}-\mathrm{Cu}$ ore in the village of Taipale. The following year a small ultra- mafic sulfide-bearing body was detected with the aid of geophysical survey and diamond drilling only a few hundred meters NW of the first ore boulder. The body was completely covered by glacial overburden.

On the basis of drilling data the ore reserves were estimated in 1963 to be 515000 tons assaying $0.48 \% \mathrm{Cu}$ and $0.55 \% \mathrm{Ni}$. The decision to exploit the ore was made in 1970 after ownership of the deposit had passed to Outokumpu Oy. In March 1971 mining operations started in an open pit. From October 1973 they continued underground until September 1974 when the whole deposit was 


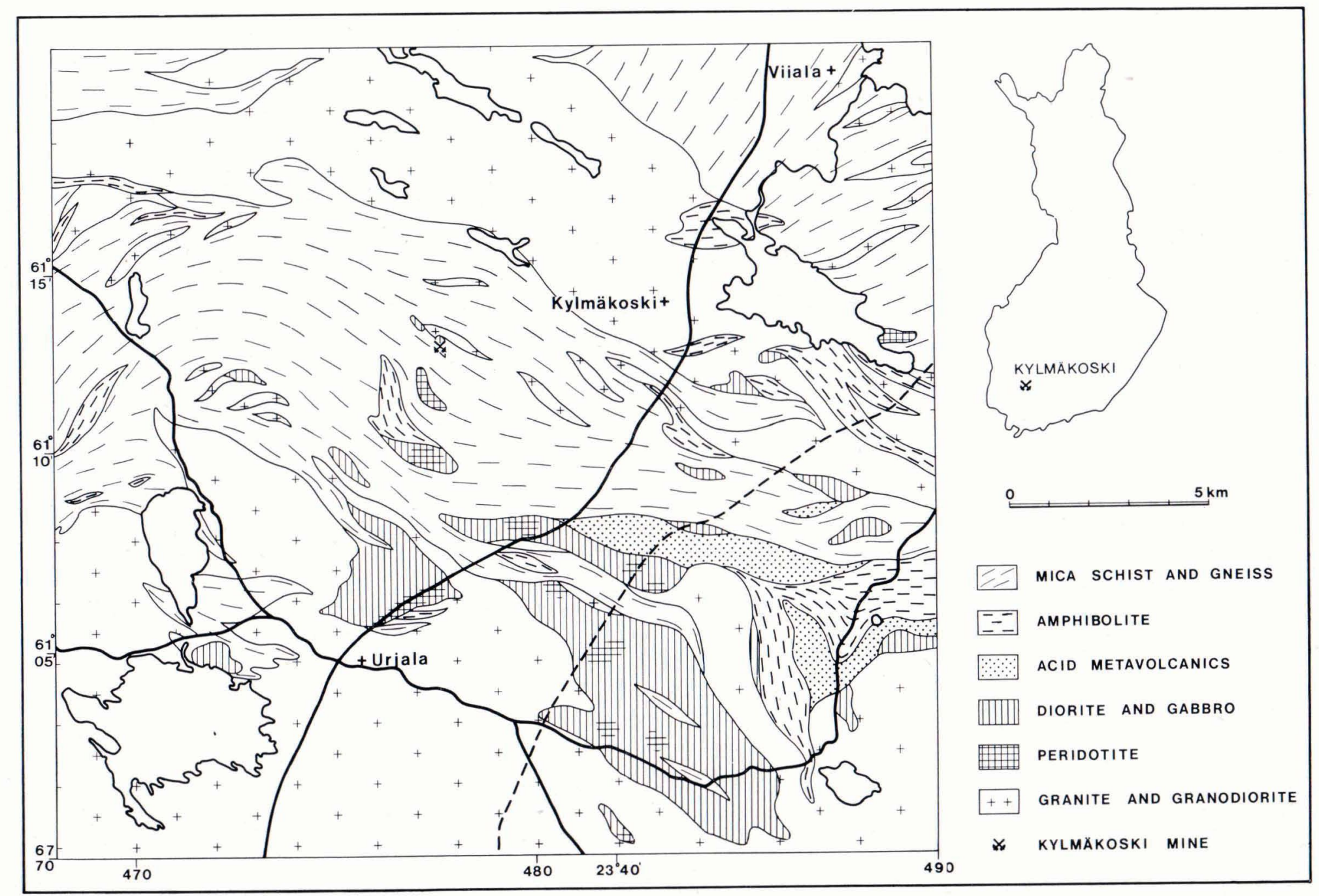


exhausted. During that period, 689616 tons of ore and 839586 tons of barren rock were hoisted. The total recovery of nickel was 1829 tons and of copper 579 tons.

The present author took part in the geological investigations by Outokumpu Oy at the end of the 1960 s and during the exploitation period of the mine. The numerous new discoveries of $\mathrm{Ni}-\mathrm{Cu}$ occurrences in the PoriKylmäkoski nickel belt and the explorational potentiality of the area warrant a detailed description of the ore deposit. A brief report of the appeared in Finnish by Papunen in 1976.

\section{General geology of the Kylmäkoski area}

Exploration for nickel and lithogeochemical study of the distribution of nickel in mafic and ultramafic rocks (Häkli, 1970, 1971) revealed a linear belt favourable for $\mathrm{Ni}-\mathrm{Cu}$ occurrences extending from Ahlainen in the northwest to Sääksmäki in the southeast. The belt is here called the Pori-Kylmäkoski belt. Papunen et al. (1979) and Häkli et al. (1979) pointed out that the belt is the southwestern segment of a ring-shaped zone that surrounds the central Finland granitoid and includes most of the Ni-Cu occurrences in the Svecofennides.

The Vammala deposit (Häkli et al. 1979) is the largest of the $\mathrm{Ni}-\mathrm{Cu}$ occurrences in the Pori-Kylmäkoski belt, which includes the occurrences of Kylmäkoski, Sääksjärvi, Harjunpää, Hyvelä and Korkeakoski (Kahma, 1973; Häkli et al. 1979).

The ultramafic body that hosts the Kylmäkoski sulfide ore is located in a migmatized gneiss belt that runs in a WNW-ESE direction about $40 \mathrm{~km}$ south of the well-preserved metasediments and metavolcanics of the Tampere schist area (cf. Eskola, 1963). The body is embedded in mica gneisses and migmatites (Fig. 1). The paleosome of migmatite is mainly biotite gneiss but bands with garnet, cordierite, hornblende or graphite are also common. Amphibolites with interbedded uralite and plagioclase porphyrites represent volcanogenic rock types of the same gneiss belt. Owing to the high degree of metamorphism and migmatization, the origin of the mica gneisses cannot be established. Locally, however, some well-preserved parts, e.g. in Sääksmäki some 20 kilometers east of Kylmäkoski, display textures similar to metaturbidites, which suggest sedimentary origin.

The migmatites are intersected by synkinematic intrusive rock series: hornblendites, gabbros, diorites and quartz diorites, which constitute a differentiation series. South of the Kylmäkoski migmatite belt, there is a large area of heterogeneous, partly porphyritic quartz diorite that includes irregular bodies of diorite, gabbro and hornblendite. In the north the Kylmäkoski migmatite belt is bordered by equigranular quartz diorite; even there, however, bodies of porphyritic granodiorite occur with porphyroblasts of potassium feldspar ranging up to $3 \mathrm{~cm}$ in diameter.

\section{Shape and environment of the ultramafic body}

The body is about $260 \mathrm{~m}$ long and a maximum of $100 \mathrm{~m}$ wide and $80 \mathrm{~m}$ deep (Fig. 2). The wide northern part of the body has migmatitic gneiss as wall rock on its western side. The same gneiss appears as lenses in the northern and northeastern contacts, but in the east, farther north and in the basal contact of the northern part, the body is surrounded by quartz diorite that also intersects the body as several dikes. The narrow southern part pinches out in depth in migmatic gneiss wall rock. Against the quartz diorite the ultramafic body exhibits crooked, locally also rectlinear contacts; against the migmati- 


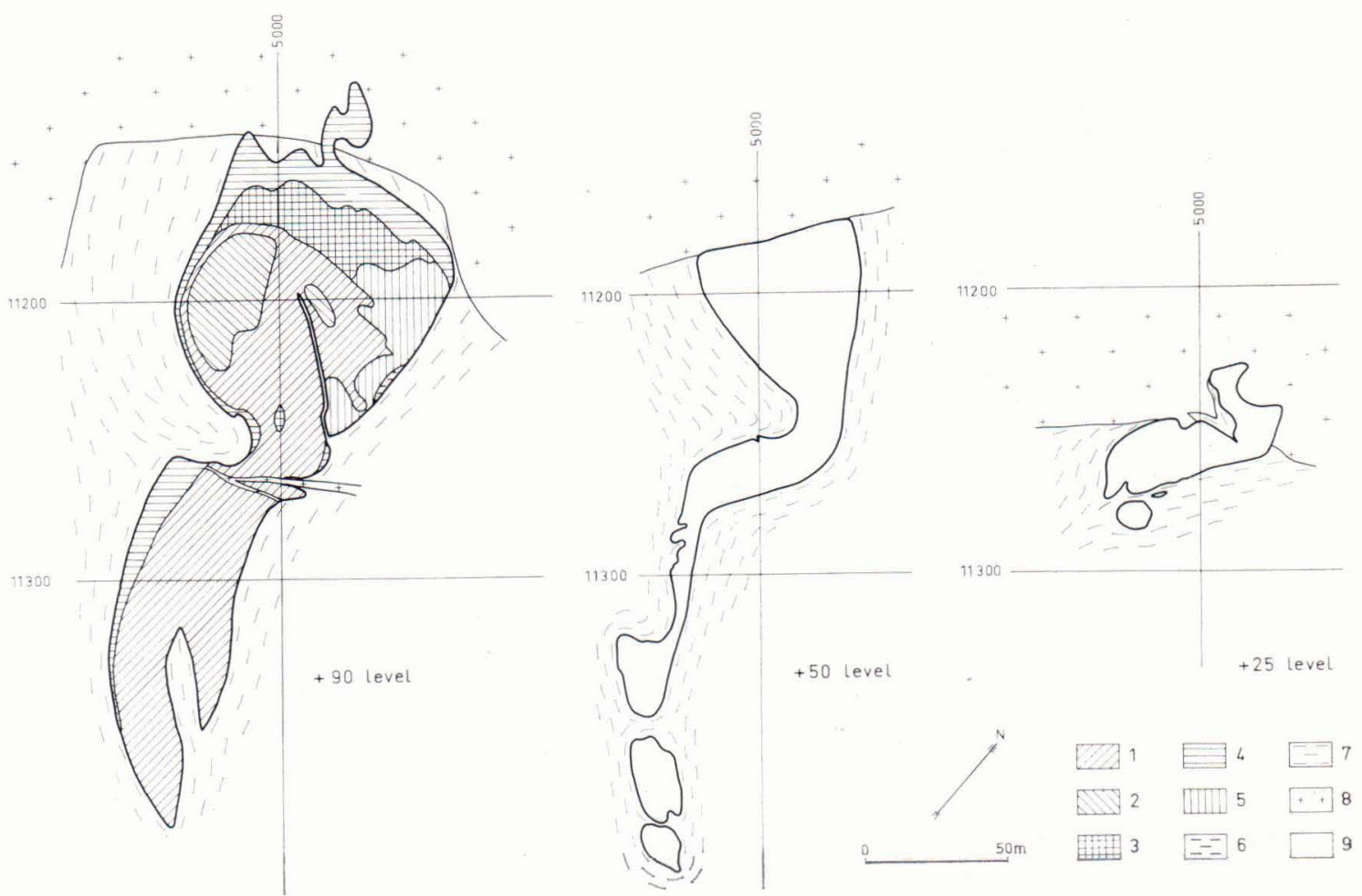

Fig. 2. The Kylmäkoski ultramafic body. Distribution of the rock types indicated only on the map of the surface level. 1. peridotite, 2. orbicular peridotite, 3. pyroxenite and perknite, 4. hornblendite, 5. cummingtonite rock, 6. gabbro, 7. migmatized mica gneiss, 8. quartz diorite, 9. ultramafite in cross sections and on plans of the +50 and +10 levels.

zed mica gneiss, however, the contact curves smoothly and in many places varies surprisingly as small scale folds that vary in axial direction as do folds in a migmatite environment (Figs. 3 and 4).
The body extends no deeper than 80 meters. The figures in sections ( +50 and +100 in Fig. 4) indicate the height above sea level; the deepest level of the mine was the $+10 \mathrm{~m}$ level. A continuation of the body beyond the

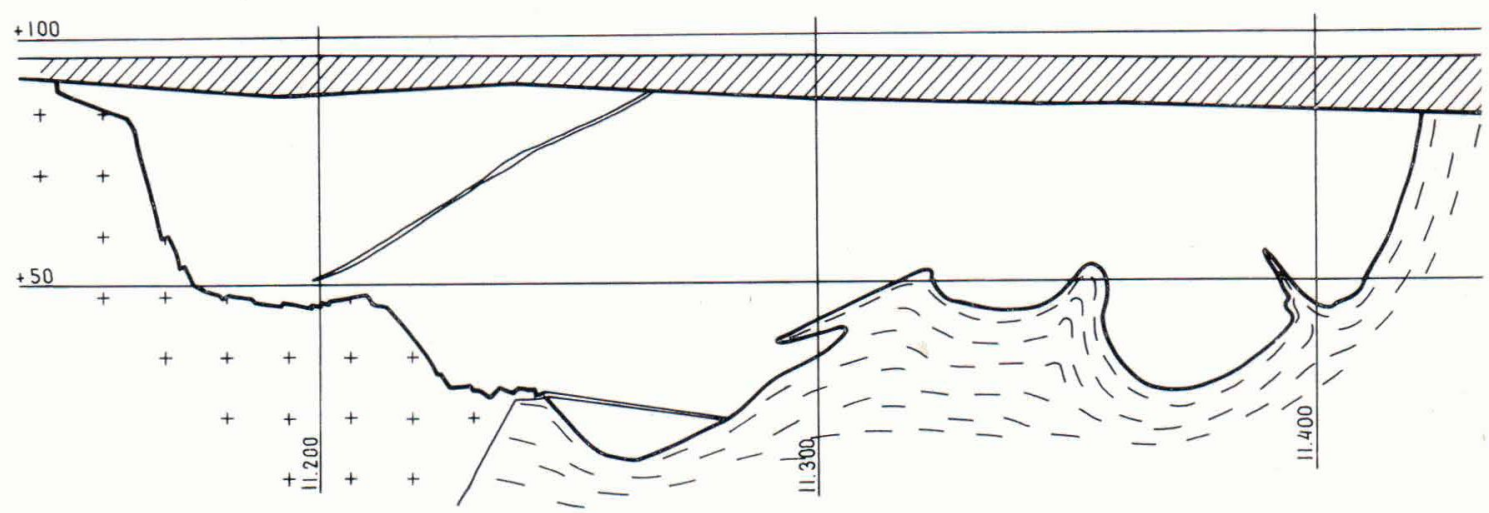

Fig. 3. Longitudinal section of the body. Legend as in Fig. 2. 

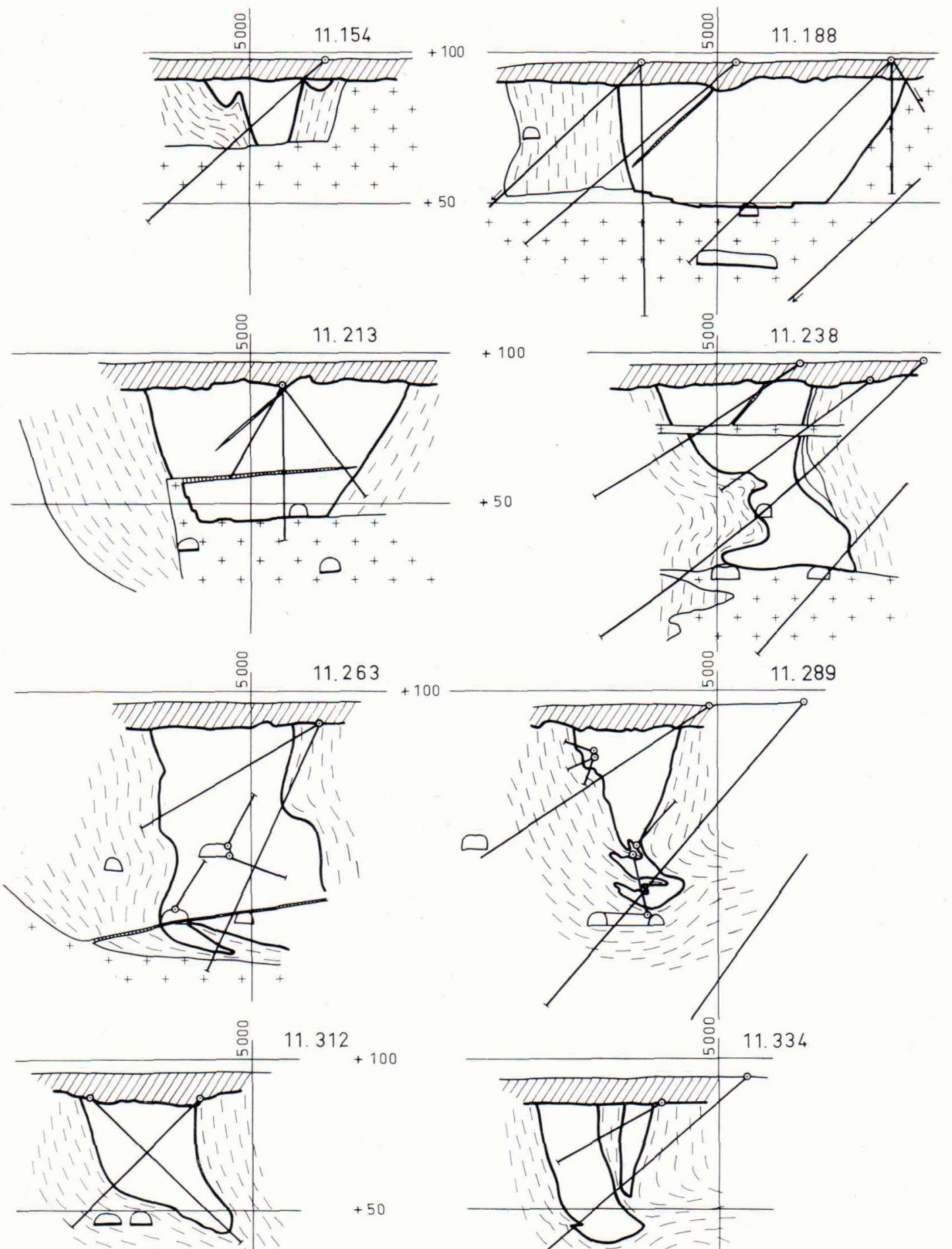

$+100$
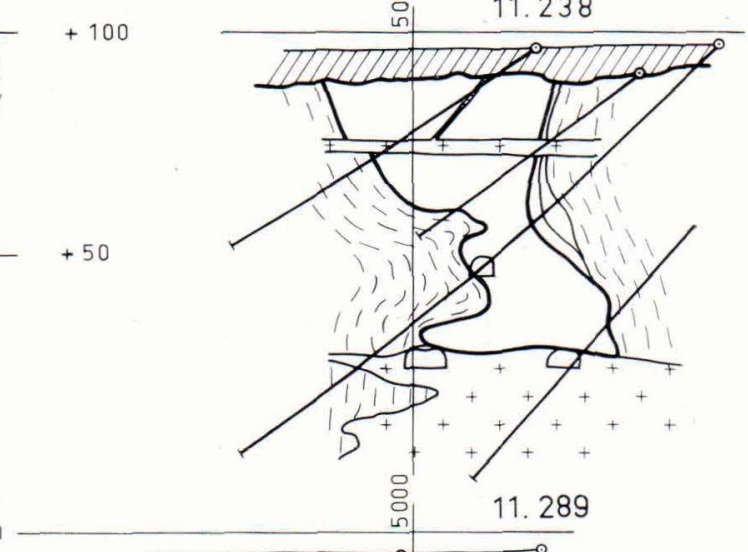


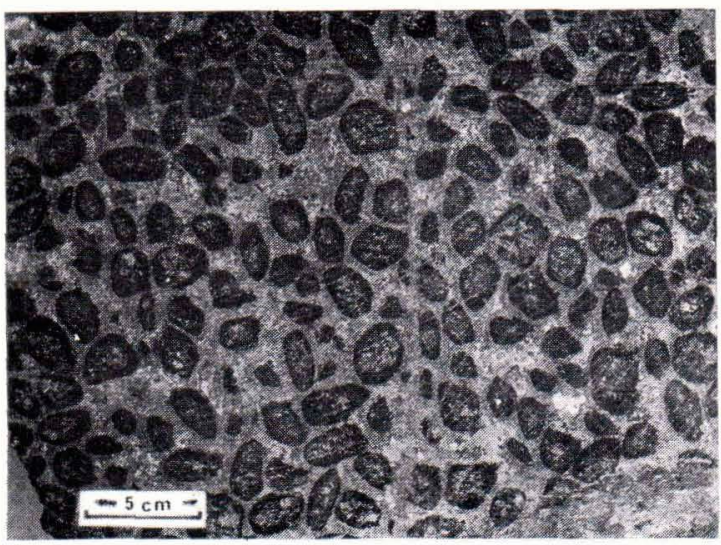

Fig. 5. Sulfide-bearing nodular peridotite. Sulfide specks appear light gray in interstices of black olivine nodules.

intruding quartz diorite in the northwest has not been established. During exploration a body of hornblendite was detected about $500 \mathrm{~m}$ northwest of the ore body, but it was barren of sulfides and the tenor of nickel was very low.

\section{The rock types}

The rock types of the ultramafic body can be classified into peridotites, pyroxenites and perknites, hornblendites, cummingtonite rocks, gabbros and diorites (Fig. 2). Peridotites abound in the central, thicker parts of the body, whereas perknites and hornblendites prevail in the tapering peripheral parts and ends of the body. Cummingtonite rocks occur only in the northern part of the body, close to its eastern contact zone. Diorites and gabbros differ from the other rock types in chemical composition and are evidently mixed contact varieties.

\section{Petrography}

Two types of peridotites occur: normal equigranular peridotite and a peculiar nodular, locally orbicular type with large oli-

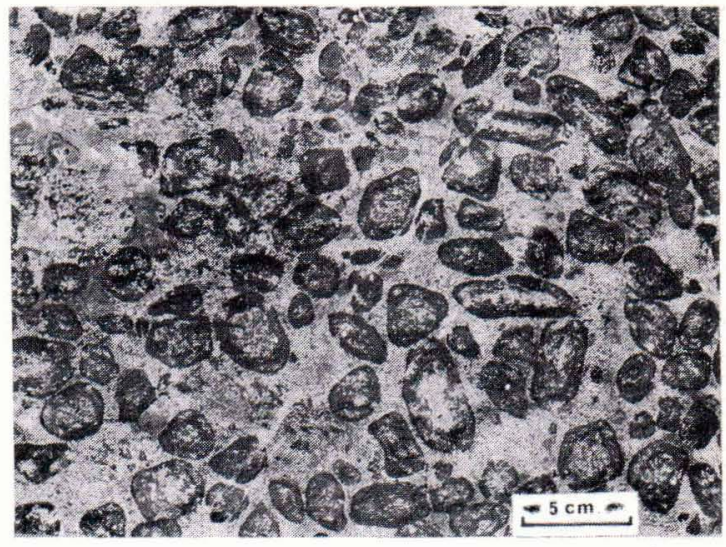

Fig. 6. Orbicular variety of peridotite. Serpentinized olivine is almost black in figure, pyroxenes and amphiboles are gray,

vine nodules. The nodular peridotite exists as irregular portions in normal peridotite in the northern end of the ultramafic body.

The normal type of peridotite consists of partially serpentinized olivine, ortho- and clinopyroxenes and brownish hornblende. Alteration processes have produced serpentine from olivine, cummingtonite from orthopyroxene and tremolite and actinolite from clinopyroxene. With increasing abundances of amphiboles the rock type grades into cummingtonite rock or hornblendite with a cortlandite variety as a transitional rock type.

The nodular peridotite is a rare rock type that has not been reported earlier. It is distinguished from the normal equigranular peridotite by its olivine nodules ranging from $1 \mathrm{~cm}$ to ca. $5 \mathrm{~cm}$ in diameter (Figs. 5 and 6). The nodules commonly exhibit external crystal forms of olivine, and in thin section they appear as large and almost equidimensional single crystals of olivine. They differ in shape from the large metamorphic blades of olivine described by Evans and Trommsdorff (1974) and also from the harrisitic or crescumulate olivine noted in some layered igneous rocks (Wager and Brown, 1968). A few nodules, however, are roundish synneutic 
Table 1. Microprobe analyses of silicate minerals in nodular peridotite.

\begin{tabular}{|c|c|c|c|c|c|c|}
\hline & \multicolumn{3}{|c|}{ Nodule } & \multicolumn{3}{|c|}{ "groundmass" } \\
\hline & \multirow{2}{*}{$\begin{array}{c}\text { Shell } \\
\text { Ol. }\end{array}$} & \multicolumn{2}{|c|}{ interior } & \multirow[b]{2}{*}{ Ol. } & \multirow[b]{2}{*}{ En } & \multirow[b]{2}{*}{ Aug } \\
\hline & & En & Aug. & & & \\
\hline $\mathrm{MgO}$ & 42.10 & 28.89 & 15.53 & 40.51 & 28.22 & 16.65 \\
\hline $\mathrm{Al}_{2} \mathrm{O}_{3}$ & & 4.97 & 0.36 & & 4.40 & 0.32 \\
\hline $\mathrm{SiO}_{2}$ & 39.77 & 53.65 & 53.88 & 39.43 & 54.66 & 53.85 \\
\hline $\mathrm{CaO}$ & & 1.14 & 23.21 & & 1.50 & 23.68 \\
\hline $\mathrm{TiO}_{2}$ & & 0.19 & 0.03 & & 0.19 & 0.03 \\
\hline $\mathrm{FeO}$ & 17.98 & 10.96 & 4.87 & 19.56 & 10.53 & 3.01 \\
\hline $\mathrm{NiO}$ & 0.18 & 0.04 & 0.01 & 0.15 & 0.03 & 0.01 \\
\hline Total & 100.03 & 99.84 & 97.89 & 99.65 & 99.53 & 97.55 \\
\hline
\end{tabular}

Ol. = olivine, $\mathrm{En}=$ enstatite, Aug. = augite

aggregates of small olivine grains. Being oriented, they give rise to a "wavy extinction" in the whole nodule under crossed polarizers. The olivine is partly, or almost wholly, serpentinized.

The "groundmass" in the intersticies of the euhedral olivine nodules is composed of medium-grained pyroxenes and amphiboles, locally also scattered olivine grains and sulfide accumulations. Only the outer shell of the nodules is usually olivine; the interior consists of coarse, locally poiklitic pyroxene and small individual olivine crystals. Thus, the material resembles the groundmass outside the nodules.

In some places the olivine shells seem to be refused, although concentric radial zoning of olivine, pyroxenes and amphiboles is also encountered. The term »orbicular» is proposed for this type. The olivine forms a roundish »eggshell» around radial or poikilitic crystals of pyroxene and amphibole (Fig. 6).

A feature common to the zoned »orbicular» type and the euhedral shells of olivine nodules is that the abundance of sulfides inside of the nodules is lower than in the external groundmass. This is probably due to sulfide liquation, which preceded the rapid crystallization of the olivine nodules. The forsterite component is highest in the olivine shell. The values are slightly lower for the groundmass olivine, which indicates early crystallization of the olivine nodules (Table 1).

The euhedral shape and large size of the nodules is a result of rapid growth of crystals in the melt. In olivine basalts the phenocrysts of olivine usually contain large inclusions of groundmass because the growing crystal had a high tendency to form perfect crystal forms. The texture of olivine in the nodular peridotite is rather similar although the scale is different. The nodules seem to be unusual skeletal crystals of olivine that crystallized rapidly from supercooled magma. The skeletal blades of olivine typical of komatiitic ultramafic lavas crystallized under the conditions of a local steep temperature gradient. The olivine nodules crystallized rapidly but either the local temperature gradient was not steep enough to produce skeletal olivine blades as in komatiites or then the magma was in movement during the crystallization of the olivines and large equidimensional crystals were formed. The chemical compositions of the different types of peridotite are given in Table 3 . The nodular type is richest in magnesium but poor in silica, indicating that it is the first member of a differentiation series.

The olivine-poor pyroxenites proper are 
Table 2. Microprobe analyses of nickel in silicate minerals (ppm).

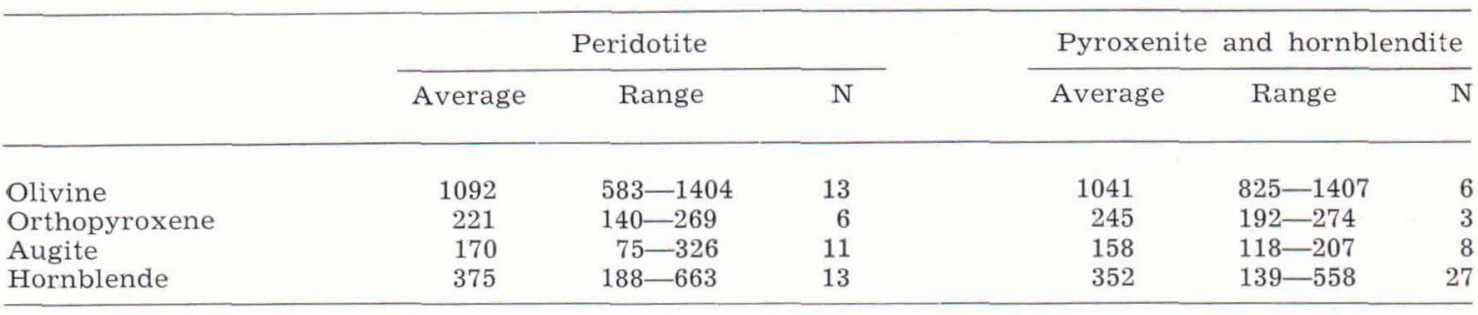

$\mathrm{N}=$ number of samples

rather uncommon, whereas the rock type known as perknite abounds in the northern part of the body. It is an ultramafite with hornblende, augite and/or hypersthene as main components and forms a transition zone from peridotite to hornblendite in the northernmost part and in the tapering southern end of the body. The hornblende is either greenish or brown in thin section. The brown hornblende seems to be a primary mineral, whereas the green variety envelopes the augite crystals and seems to be, at least partially of secondary origin. Minor plagioclase exists locally, and the rock type grades in to hornblende melagabbro or gabbro.

The rock type characterized by abundant cummingtonite is met with in the northeastern part of the body. If often contains remnants of orthopyroxene, augite and hornblende in addition to pale, intensely twinned laths of cummingtonite. The microscopic textures indicate that the rock type is an alteration product of pyroxenite.

Gabbros and diorites are quite rare. As mentioned above, the hornblendite grades into gabbro with increasing plagioclase abundances, but these variants are local and restricted in size. Diorite has been met with on the surface level close to the eastern contact of the body. In addition to hornblende, plagioclase and biotite it contains some quartz and abundant graphite. The rock is heterogeneous and the amounts of the main compo- nents vary within wide limits. Gabbros and especially the graphite-bearing diorite were formed as a result of assimilation of the wallrock material by ultramafic magma. This is supported by evidence from sulfur isotope determinations (Papunen and Mäkelä, 1980).

A set of coarse-grained and very dark pegmatite veins intersect the peridotite, especially on the +45 level in the mine. At the contacts of the pegmatite the peridotite exhibits an almost monomineralic succession of alteration zones composed of talc, actinolite, anthophyllite and chlorite in this order, starting from the unaltered peridotite. The alteration zones are from 1 to $10 \mathrm{~cm}$ wide except at the contacts of the intersecting quartzdiorite dikes, where they may be up to $20 \mathrm{~cm}$ wide. The alteration zones exist only when the peridotite is the host rock of the dikes. The contacts of pegmatite against pyroxenite or hornblendite are sharp and without alteration features. Similar zoning has been described from Hitura and Kotalahti by Papunen (1970).

\section{Chemical composition of silicate minerals}

Mafic silicates were analyzed for $\mathrm{Ni}$ and $\mathrm{Fe}$ by electron microprobe in the laboratory of the Exploration department of Outokumpu Oy. In addition to the data given in Tables 1 and 2 , the tenor of $\mathrm{Ni}$ in biotite from mica gneiss ranges from 80 to $134 \mathrm{ppm}$, averaging 
Table 3. Average chemical compositions of the rock types.

\begin{tabular}{|c|c|c|c|c|c|c|c|c|c|c|}
\hline \multirow[t]{2}{*}{$\begin{array}{l}\text { Number of } \\
\text { samples }\end{array}$} & \multicolumn{2}{|c|}{$\begin{array}{c}\text { Nodular } \\
\text { peridotite } \\
9\end{array}$} & \multicolumn{2}{|c|}{$\begin{array}{c}\text { Peridotite } \\
16\end{array}$} & \multicolumn{2}{|c|}{$\begin{array}{c}\text { Pyroxenite } \\
8\end{array}$} & \multicolumn{2}{|c|}{$\begin{array}{c}\text { Hornblendite } \\
25\end{array}$} & \multicolumn{2}{|c|}{$\begin{array}{c}\text { Gabbro } \\
4\end{array}$} \\
\hline & $\mathrm{X}$ & s.d. & $\mathrm{X}$ & s.d. & $\mathrm{X}$ & s.d. & $\mathrm{X}$ & s.d. & $\mathrm{x}$ & s.d. \\
\hline $\mathrm{SiO}_{2}$ & 39.91 & 0.95 & 46.08 & 2.19 & 49.20 & 3.55 & 49.00 & 3.19 & 45.08 & 3.03 \\
\hline $\mathrm{TiO}_{2}$ & 0.36 & 0.15 & 0.30 & 0.17 & 0.44 & 0.22 & 0.50 & 0.24 & 1.05 & 0.74 \\
\hline $\mathrm{Al}_{2} \mathrm{O}_{3}$ & 2.99 & 0.45 & 4.34 & 1.53 & 5.63 & 1.88 & 6.12 & 1.49 & 17.02 & 2.18 \\
\hline $\mathrm{FeO}$ (total) & 14.34 & 0.42 & 13.45 & 1.39 & 13.03 & 0.83 & 11.92 & 2.70 & 14.91 & 4.36 \\
\hline $\mathrm{FeO}$ (silic.) & 12.91 & 0.89 & 12.04 & 1.47 & 11.05 & 1.94 & 9.56 & 1.26 & 14.12 & 3.79 \\
\hline $\mathrm{MnO}$ & 0.19 & 0.02 & 0.19 & 0.02 & 0.19 & 0.03 & 0.18 & 0.04 & 0.21 & 0.06 \\
\hline $\mathrm{MgO}$ & 28.33 & 1.59 & 23.50 & 1.49 & 19.49 & 0.78 & 15.30 & 1.50 & 9.44 & 2.61 \\
\hline $\mathrm{CaO}$ & 4.07 & 0.69 & 7.84 & 2.03 & 8.84 & 1.14 & 12.10 & 1.75 & 8.18 & 3.87 \\
\hline $\mathrm{Na}_{2} \mathrm{O}$ & 0.09 & 0.10 & 0.31 & 0.32 & 0.64 & 0.45 & 0.61 & 0.26 & 1.07 & 0.33 \\
\hline $\mathrm{K}_{2} \mathrm{O}$ & 0.06 & 0.07 & 0.08 & 0.10 & 0.08 & 0.09 & 0.22 & 0.18 & 1.33 & 0.31 \\
\hline $\mathrm{P}$ & 0.06 & 0.01 & 0.11 & 0.15 & 0.11 & 0.03 & 0.19 & 0.06 & 0.14 & 0.08 \\
\hline S & 1.06 & 0.76 & 1.05 & 1.06 & 1.48 & 1.21 & 1.77 & 1.51 & 0.59 & 0.76 \\
\hline As & 0.002 & - & 0.010 & 0.005 & 0.004 & - & 0.00 & - & 0.00 & - \\
\hline $\mathrm{Cu}$ & 0.15 & 0.10 & 0.21 & 0.32 & 0.19 & 0.19 & 0.14 & 0.12 & 0.06 & 0.08 \\
\hline $\mathrm{Ni}$ (total) & 0.25 & 0.12 & 0.26 & 0.20 & 0.24 & 0.17 & 0.26 & 0.21 & 0.09 & 0.12 \\
\hline $\mathrm{Cr}$ & 0.09 & 0.05 & 0.28 & 0.14 & 0.28 & 0.16 & 0.43 & 0.13 & 0.06 & 0.04 \\
\hline
\end{tabular}

$\mathrm{X}=$ arithmetic mean, s.d. $=$ standard deviation

$97 \mathrm{ppm}$. The content of nickel in the hornblende of the enclosing quartz diorite is only $18 \mathrm{ppm}$; the highest abundances of nickel from 874 to $988 \mathrm{ppm}$ were recorded from two thin quartz diorite dikes intersecting the peridotite. A hornblende gabbro at the contact of ultramafite has only 28 to $56 \mathrm{ppm}$ nickel in hornblende, indicating that the gabbro belongs to the synorogenic intrusive suite, which farther south shown rather similar values.

The abundance of nickel in olivine is about the same as that in the lower, sulfide-rich ultramafic layer of the Stormi intrusion; at Kylmäkoski, however, the Fo content of olivine is somewhat lower (Häkli et al. 1979). There is no correlation between $\mathrm{Ni}$ and $\mathrm{Fo}$ abundances in olivine and in this respect, too, the variation in composition is similar to that in the Stormi ultramafite. In a small sulfide-bearing intrusive like that at Kylmäkoski the subsolidus reactions between olivine and sulfides equilibrated the composition of sulfide and silicate phases at a certain level.

\section{Geochemistry of the rock types}

The samples were analyzed at the Exploration Department of Outokumpu Oy by the XRF method described by Häkli et al. (1979). The results are given as calculated averages for different rock types (Table 3) and as ternary diagrams (Fig. 7). The chemical compositions of the rock types are similar to those for the Stormi ultramafic complex (Häkli et al. 1979), except that the dunitic member is lacking in Kylmäkoski. The nodular peridotite is the most mafic member of the Kylmäkoski rock series. In the ultramafic rocks of the suite the ratio $\mathrm{Ca}$ to $\mathrm{Al}$ is generally more than unity. The variation in the $\mathrm{Mg}$ to $\mathrm{Fe}$ ratio from nodular peridotite to hornblendite is small, but the compositional difference is manifest in the abundances of calcium, aluminium and alkalies.

Häkli et al. (1979) explained the similar variation within the Stormi ultramafic complex as a result of migration of these elements from the wall rock into the ultramafic 

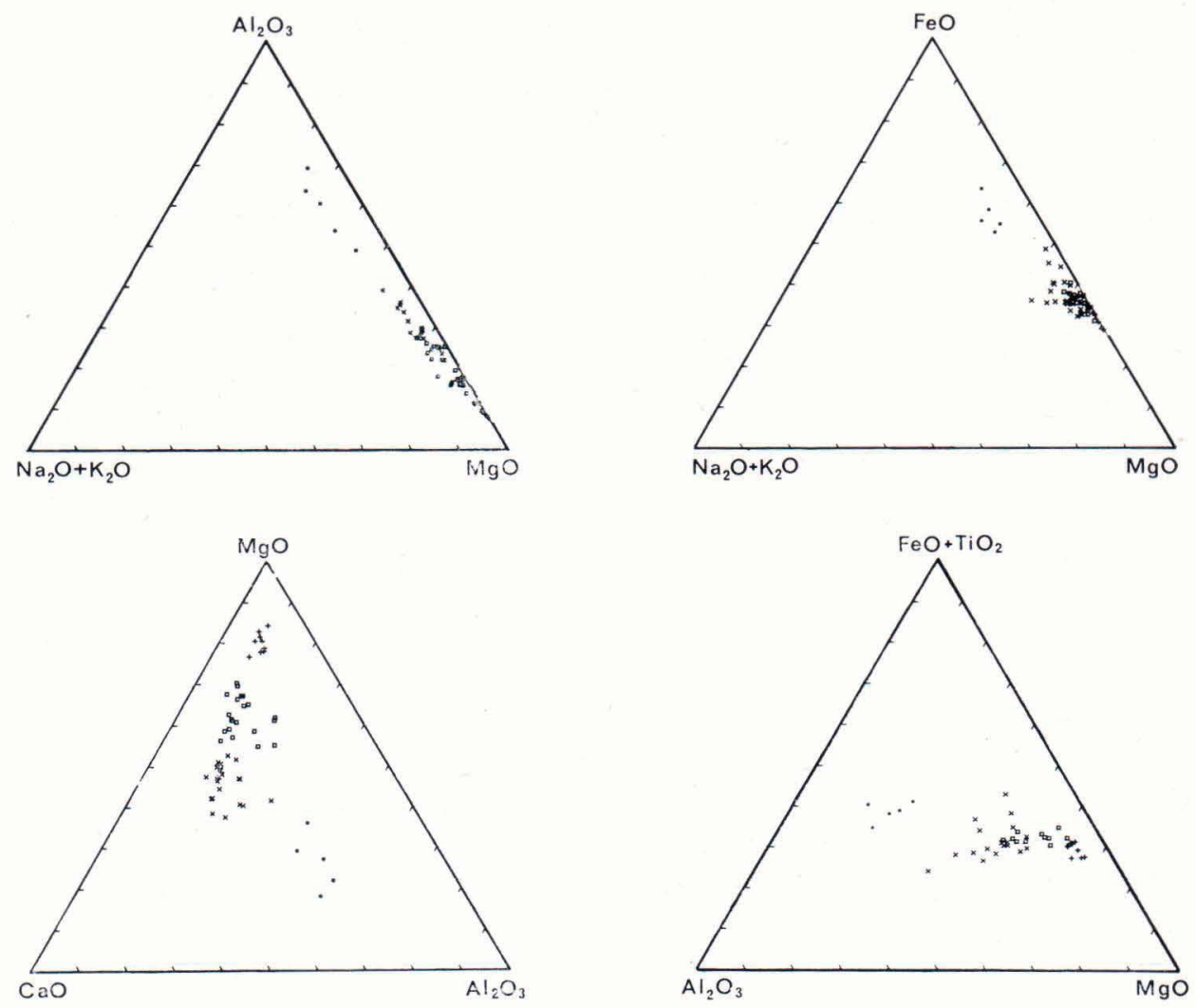

Fig. 7. Ternary diagrams depicting the variation in chemical composition of the rock types. $+=$ orbicular and nodular peridotite, square $=$ peridotite and pyroxenite, $\mathrm{x}=$ hornblendite, $\bullet=$ gabbro

magma. The same explanation can well be applied to the Kylmäkoski rock series. The location of hornblendites at the contacts and in the tapering ends of the body support this concept. The heterogeneous graphite-rich gabbros and diorites assimilated a graphiterich portion of the wall rock.

\section{The ore types}

The sulfide minerals exist mainly as dissemination, which is locally abundant enough to form a continuous net between the silicates. In the olivine- and pyroxene-rich peridotites the dissemination is interstitial (Fig. 8), but in the hornblendite the sulfides often exist as round spheres indicating that they crys- tallized earlier than the host hornblende. In the nodular peridotite the sulfides occasionally occur as small massive layers that grade upward into an interstitial dissemination between nodules of the overlying peridotite. In the coarse-grained dissemination in the nodular peridotite, chalcopyrite is often seen close to the top edges of the sulfide grains that rest on the olivine nodules. The texture demonstrates that the heavy sulfide drops settled down as massive layers in a melt that contained large nodules of previously crystallized olivine. The texture lends excellent support to the »billiard-ball model» by Naldrett (1973). Along the basal contacts of the body the sulfides occur as fine-grained breccias that locally extend for a few meters into 


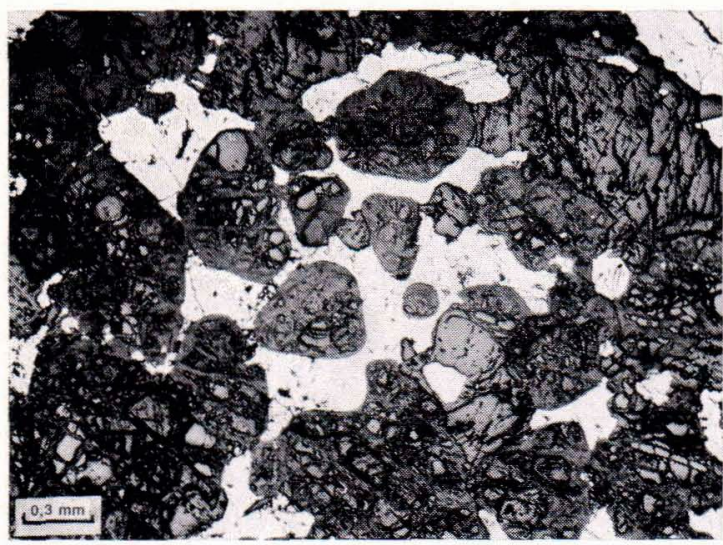

Fig. 8. Interstitial pyrrhotite-pentlandite dissemination (white) in peridotite; reflected light.

the wall rock gneiss. In cummingtonite rocks the sulfides exist as anhedral grains penetrated by amphibole needles as a result of metamorphic recrystallization of amphibole (Fig. 9). The sulfides also form rectlinear massive veins up to $20 \mathrm{~cm}$ wide that can be followed for over ten meters. The veins are enveloped by chlorite-rich slickensides that, when the sulfide vein dies out, continue without sulfides. Massive Ni-arsenides occur locally as a continuation of the massive $\mathrm{Ni}-\mathrm{Cu}$ sulfides in the veins. As a rule however, the nickel arsenide veins are encountered as the taper-

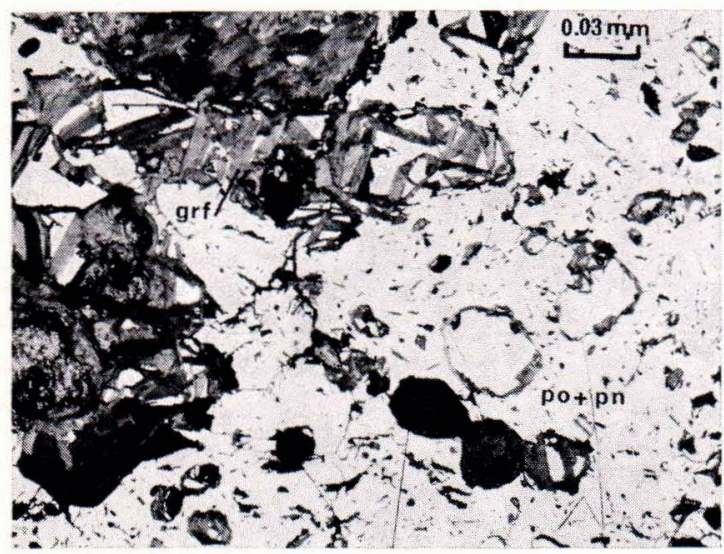

Fig. 10. Graphite-rich breccia ore; po = pyrrhotite, $\quad \mathrm{pn}=$ pentlandite, grf $=$ graphite; reflected light.

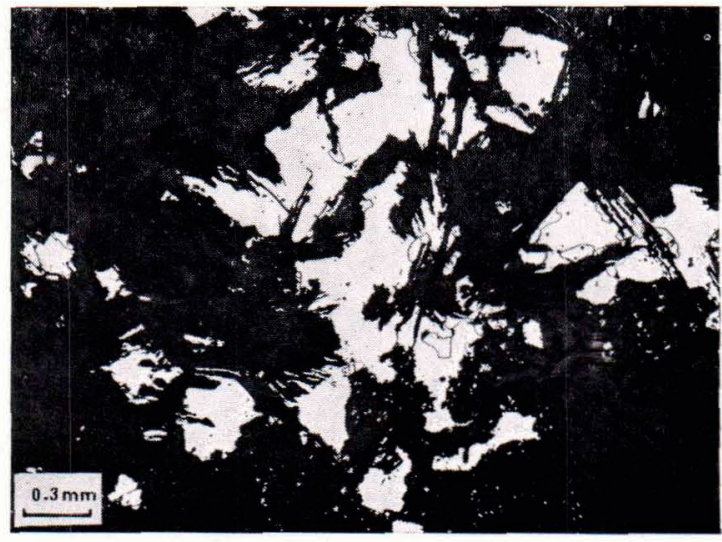

Fig. 9. Pyrrhotite-pentlandite grains (white) intersected by amphibole needles in cummingtonite rock; reflected light.

ing ends of quartz-diorite dikes or in contact shear zones of the intrusive quartz diorite.

\section{The ore minerals}

The main ore minerals in the disseminated and breccia ores are pyrrhotite, pentlandite and chalcopyrite, but, especially in the breccias rich in $\mathrm{Cu}$, lamellae of cubanite are almost as abundant as chalcopyrite (Fig. 13). The same is true for the dissemination in the cummingtonite rock. Pyrrhotite is mainly of hexagonal phase, but in the breccia ores a

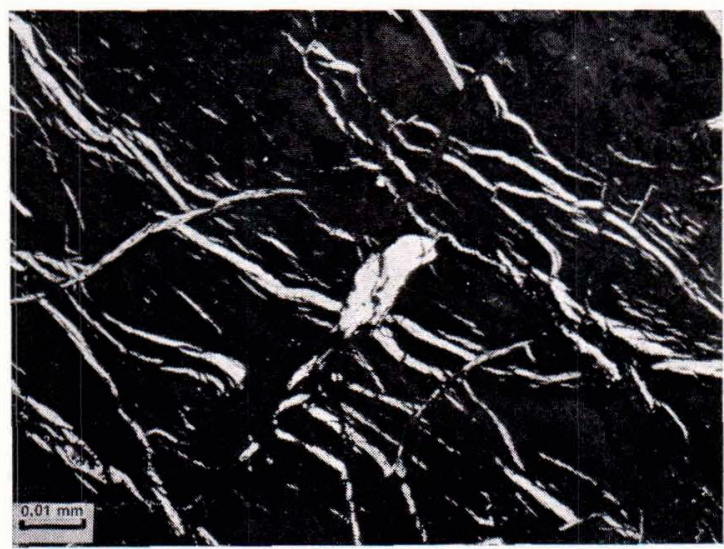

Fig. 11. Mackinawite (white) in serpentinized olivine (black); reflected light. 


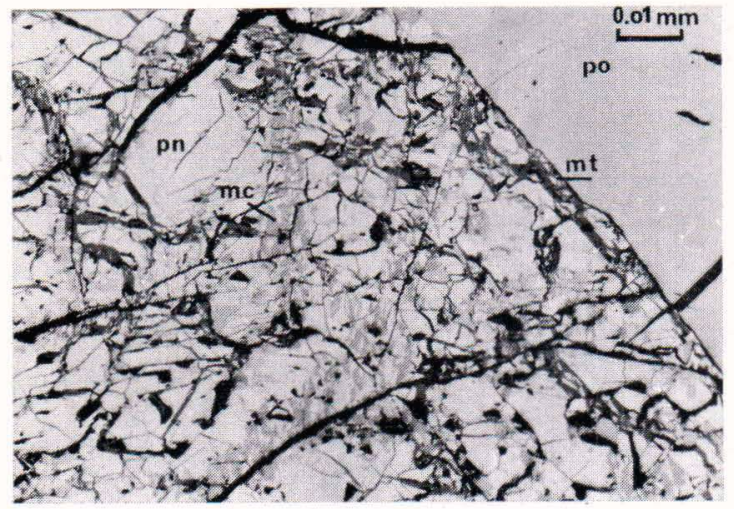

Fig. 12. Mackinawite (mc) and magnetite (mt) replacing pentlandite $(\mathrm{pn})$, po = pyrrhotite; reflected light.

minor amount of monoclinic phase appears as lamellae in the hexagonal host. Euhedral pentlandite grains are common in the dissemination in peridotite, whereas granular pentlandite and exsolution flakes abound in the other ore types. In some places pentlandite hosts lamellae of exsolved chalcopyrite. The pentlandite crystals of serpentinized peridotite contain a network of serpentine and magnetite along the octahedral cracks, a texture that impeded the benefication of the ore (Fig. 12).

The minor opaque minerals include mackinawite, which occurs especially in the serpentinized parts of the body as small oriented flakes in pentlandite (Fig. 12) or as small flake veinlets along former cracks of serpentinized olivine grains (Fig. 11) and also as independent dissemination in serpentinite. The texture of the mackinawite is similar to that of secondary magnetite which occasionally abounds in cracks of pentlandite and in serpentinized olivine. Graphite is locally very common in the eastern part of the body (Fig. 10). It exists in brecciated ores as large flakes or as a fine-grained mass, and it may form round spheres in pyrrhotite. Some flakes of molybdenite are met with in the

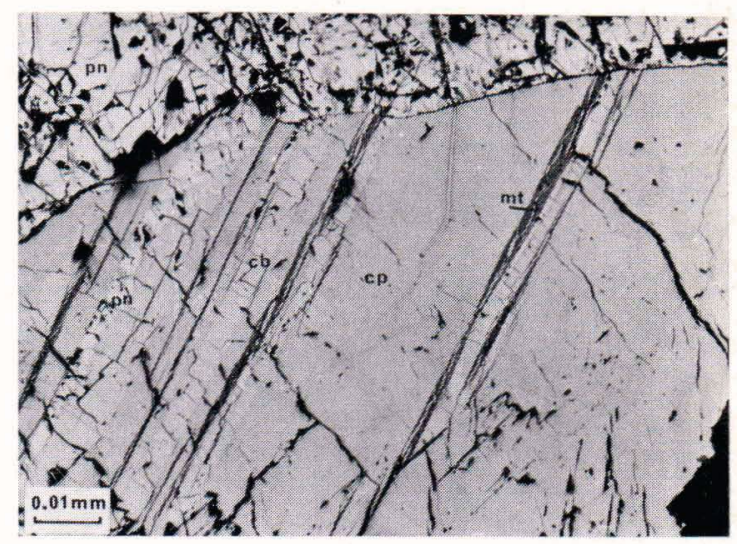

Fig. 13. Lamellar intergrowth of pentlandite (pn) and cubanite $(\mathrm{cb})$ in chalcopyrite $(\mathrm{cp}) ; \mathrm{mt}=\mathrm{mag}-$ netite.

graphite-rich part of the body. Argentian pentlandite is a common minor constituent of the chalcopyrite-rich ores in breccias and sulfide veins. In the disseminated ores rare euhedral grains of gersdorffite-cobaltite are encountered together with sulfides; in the nickel arsenide veins, however, zoned grains of gersdorffite-cobaltite are locally the main opaque minerals. Nickeline and maucherite are often the predominant minerals in the arsenide veins. A cobaltite-gersdorffite seam exists between the sulfides and arsenides in localities where an arsenide vein terminates in a sulfide vein. Nickeline is more abundant than maucherite and it commonly contains minute euhedral inclusions of gersdorffite. The mineral assemblage of the arsenide veins also includes chalcopyrite with abundant argentian pentlandite, common pentlandite and minor wehrlite and galena as well as minerals of PGE, of which michenerite has been identified.

The chemical compositions of the main ore minerals are given in Table 4. The nickel to iron ratio of pentlandite is lowest in the disseminated ore in peridotite, in which the average iron to sulfur ratio of pyrrhotite is highest. Both are in accordance with the 
Table 4. Electron microprobe analyses of sulfides (mean compositions).

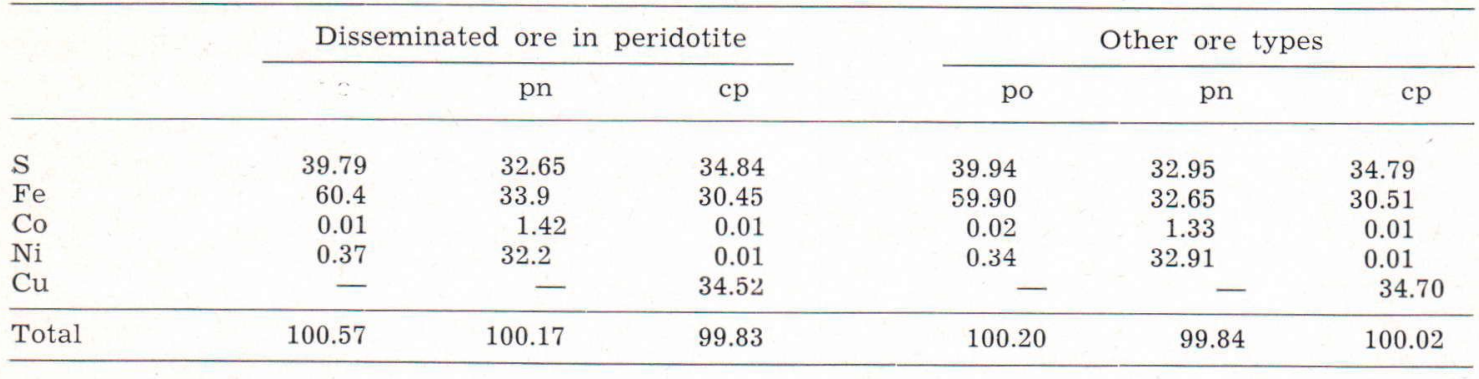

po $=$ pyrrhotite, $\mathrm{pn}=$ pentlandite, $\mathrm{cp}=$ chalcopyrite

composition of sulfide minerals and sulfide phase as reported from Hitura and Kotalahti by Papunen (1970, 1974).

\section{Composition of the sulfide phase}

A set of samples of every rock and ore type (281 in all) was collected from drill cores from different parts of the body. The sulfides were leached with bromine methanol and the base metals were assayed with AAS at the Laboratory of Exploration, Outokumpu Oy, according to the method described by Penttinen et al. (1977). The sulfur was determined by an automatic Leco sulfur analyzer. The average compositions of the different ore types are given in Table 5 .

The correlation coefficients were calculated (Table 6) and the R-mode factor analysis was performed from the logarithms of the anal- ytical data. The factor matrix was rotated by the Varimax method; the first four factors are presented in Table 7 . The factor scores of each analyzed sample were also calculated.

The first factor, which has high loadings of $\mathrm{Cu}, \mathrm{Ni}, \mathrm{Co}$ and $\mathrm{S}$, is called the "nickel ore factor». The second factor has high loadings of the copper to sulfur ratio indicating a high copper content in the sulfide phase. Correspondingly the third factor has a high loading of the Ni to $\mathrm{S}$ ratio. The fourth factor has loadings of $\mathrm{Zn}, \mathrm{Pb}$ and $\mathrm{Ag}$ but, owing to the low eigenvalue, it is of minor significance.

Comparison of the factor scores with the sulfide mineral assemblages of the samples clearly demonstrates a correlation between a definite assemblage and high values of factor scores. The first factor has the highest values in the samples with high contents of the main ore minerals, pyrrhotite, pentlandite and chal-

Table 5. Average chemical compositions of the sulfide fractions (percent).

\begin{tabular}{|c|c|c|c|c|c|}
\hline & $\mathrm{Ni}$ & $\mathrm{Cu}$ & Co & $\mathrm{Zn} \mathrm{ppm}$ & $\mathrm{Pb} \mathrm{ppm}$ \\
\hline Nodular peridotite & 7.07 & 3.74 & 0.39 & 941 & 503 \\
\hline Peridotite & 6.69 & 3.52 & 0.33 & 840 & 428 \\
\hline Pyroxenite & 5.20 & 3.74 & 0.31 & 503 & 319 \\
\hline Gummingtonite rock & 5.22 & 2.98 & 0.25 & 518 & 293 \\
\hline Hornblendite & 4.98 & 2.91 & 0.25 & 623 & 349 \\
\hline $\begin{array}{l}\text { Breccia ore at the } \\
\text { contact of the body }\end{array}$ & 4.59 & 22.7 & 0.18 & 1916 & 465 \\
\hline Sulfide vein & 5.06 & 0.59 & 0.26 & 139 & 19 \\
\hline
\end{tabular}

Calculated assuming $37.5 \% \mathrm{~S}$ in the sulfide phase 
Table 6. Correlation coefficients.

\begin{tabular}{lrrrrrrrrrr}
\hline & $\mathrm{Cu}$ & $\mathrm{Zn}$ & $\mathrm{Ni}$ & $\mathrm{Co}$ & $\mathrm{Pb}$ & $\mathrm{Ag}$ & $\mathrm{S}$ & $\mathrm{Cu} / \mathrm{S}$ & $\mathrm{Ni} / \mathrm{S}$ & $\mathrm{Ni} / \mathrm{Co}$ \\
\hline $\mathrm{Cu}$ & & & & & & & & & & \\
$\mathrm{Zn}$ & 1.00 & .46 & .75 & .63 & .37 & .78 & .79 & .40 & -.08 & .75 \\
$\mathrm{Ni}$ & .45 & 1.00 & .23 & .20 & .51 & .56 & .20 & .43 & .08 & .23 \\
$\mathrm{Co}$ & .75 & .23 & 1.00 & .94 & .44 & .57 & .91 & -.18 & .24 & .87 \\
$\mathrm{~Pb}$ & .63 & .20 & .93 & 1.00 & .49 & .46 & .87 & .30 & .19 \\
$\mathrm{Ag}$ & .37 & .51 & .44 & .49 & 1.00 & .46 & .37 & .04 & .18 & .27 \\
$\mathrm{~S}$ & .78 & .56 & .57 & .46 & .46 & 1.00 & .60 & .34 & .06 & .58 \\
$\mathrm{Cu} / \mathrm{S}$ & .79 & .20 & .91 & .87 & .37 & .60 & 1.00 & .24 & .18 \\
$\mathrm{Ni} / \mathrm{S}$ & .40 & .43 & -.18 & -.30 & .04 & .34 & -.24 & 1.00 & .14 & .04 \\
$\mathrm{Ni} / \mathrm{Co}$ & -.08 & .09 & .24 & .20 & .18 & .06 & .18 & .14 & .00 & .25 \\
\hline
\end{tabular}

Table 7. Rotated factor matrix.

\begin{tabular}{|c|c|c|c|c|c|}
\hline & \multicolumn{4}{|c|}{ Factors } & \multirow{2}{*}{ Communalities } \\
\hline & 1. & 2. & 3. & 4. & \\
\hline $\mathrm{Cu}$ & .816 & .476 & .167 & .210 & 0.965 \\
\hline $\mathrm{Zn}$ & .127 & .487 & -.119 & .734 & 0.792 \\
\hline $\mathrm{Ni}$ & .955 & -.107 & .175 & .206 & 0.997 \\
\hline Co & .847 & -.289 & .130 & .310 & 0.914 \\
\hline $\mathrm{Pb}$ & .252 & -.066 & .120 & .890 & 0.873 \\
\hline Ag & .607 & .469 & -.190 & .424 & 0.804 \\
\hline S & .942 & -.131 & -.245 & .174 & 0.995 \\
\hline $\mathrm{Cu} / \mathrm{S}$ & -.116 & .951 & .102 & .071 & 0.935 \\
\hline $\mathrm{Ni} / \mathrm{S}$ & .059 & .055 & .989 & .081 & 0.993 \\
\hline $\mathrm{Ni} / \mathrm{Co}$ & .987 & .176 & .202 & .010 & 0.877 \\
\hline eigenvalues & 5.10 & 1.87 & 1.24 & 0.94 & \\
\hline $\begin{array}{l}\text { cumulative } \\
\text { percentage } \\
\text { of total } \\
\text { variance }\end{array}$ & 51.00 & 69.70 & 82.08 & 91.44 & \\
\hline $\begin{array}{l}\text { principal } \\
\text { loadings }\end{array}$ & $\begin{array}{l}\mathrm{Cu} \\
\mathrm{Ni} \\
\mathrm{Co} \\
\mathrm{S} \\
\mathrm{Ag} \\
\mathrm{Ni} / \mathrm{Co}\end{array}$ & $\begin{array}{l}\mathrm{Cu} / \mathrm{S} \\
(\mathrm{Ag}) \\
(\mathrm{Zn}) \\
(\mathrm{Cu})\end{array}$ & $\mathrm{Ni} / \mathrm{S}$ & $\begin{array}{l}\mathrm{Zn} \\
\mathrm{Pb} \\
(\mathrm{Ag})\end{array}$ & \\
\hline
\end{tabular}

copyrite, whereas the second factor shows high values in samples with chalcopyrite and cubanite as the main sulfide minerals. The loadings of silver and zinc on this factor can be explained by the fact that the main carrier of silver, argentian pentlandite, as well the zinc mineral, sphalerite, exist as exsolution bodies in chalcopyrite. The third factor has high factor scores in the samples with $\mathrm{Ni}$ arsenide mineralization, in which the ratio $\mathrm{Ni}$ to sulfur becomes anomalously high.

In this particular case factor analysis of the geochemical data of the ore samples correlates very well with the mineral assemblages, and the factor scores indicate quantitatively the abundances of different ore mineral assemblages.

A representative set of samples was col- 
Table 8. Abundances of PGE (ppm).

\begin{tabular}{lcccc}
\hline Sample & Pt & Pd & Rh & S (per cent) \\
\hline chalcopyrite-rich impregnation & & & & \\
in perknite & $<0.005$ & 0.0025 & $<.005$ & 8.2 \\
peridotite, disseminated sulfides & 0.01 & 0.005 & $<0.005$ & 2.15 \\
orbicular peridotite & $<0.005$ & 0.0025 & $<.005$ & 3.40 \\
peridotite, rich dissemination & 0.005 & 0.0035 & $<0.005$ & 2.05 \\
pyroxene-hornblende gabbro & 0.01 & 0.025 & $<0.005$ & 13.6 \\
breccia ore in perknite & $<0.005$ & 0.005 & $<0.005$ & 15.0 \\
breccia ore in hornblendite & 0.005 & 0.005 & $<0.005$ & 35.6 \\
massive ore & $<0.005$ & 0.001 & $<0.005$ & - \\
nickel arsenide vein & 0.4 & 1.0 & \\
\hline
\end{tabular}

Table 9. Lead isotope analytical data for chalcopyrite fractions.

\begin{tabular}{|c|c|c|c|c|}
\hline \multicolumn{2}{|c|}{ Sample } & \multirow{2}{*}{$\frac{{ }^{206} \mathrm{~Pb} /{ }^{204} \mathrm{~Pb}}{19.320}$} & \multirow{2}{*}{$\frac{{ }^{207} \mathrm{~Pb} / 204 \mathrm{~Pb}}{15.802}$} & \multirow{2}{*}{$\begin{array}{c}{ }^{208} \mathrm{~Pb} / 204 \mathrm{~Pb} \\
38.604\end{array}$} \\
\hline A. & disseminated $\mathrm{Cu}$-rich ore & & & \\
\hline & in hornblendite & \pm 0.052 & \pm 0.044 & \pm 0.116 \\
\hline \multirow[t]{2}{*}{ B. } & disseminated ore in & 24.384 & 16.340 & 48.303 \\
\hline & pyroxenite & \pm 0.035 & \pm 0.031 & \pm 0.086 \\
\hline \multirow[t]{2}{*}{ C. } & disseminated ore in & 23.864 & 16.293 & 37.720 \\
\hline & peridotite & \pm 0.024 & \pm 0.028 & \pm 0.049 \\
\hline \multirow[t]{2}{*}{ D. } & sulfide vein in & 17.811 & 15.603 & 36.918 \\
\hline & peridotite & \pm 0.001 & \pm 0.005 & \pm 0.014 \\
\hline \multirow[t]{2}{*}{ E. } & chalcopyrite rich breccia & 24.002 & 16.305 & 41.569 \\
\hline & $\begin{array}{l}\text { in gneiss at the contact } \\
\text { of peridotite }\end{array}$ & \pm 0.007 & \pm 0.013 & \pm 0.026 \\
\hline & disseminated ore in orbicular & 18.089 & 15.616 & 37.240 \\
\hline & peridotite & \pm 0.016 & \pm 0.017 & \pm 0.043 \\
\hline
\end{tabular}

lected for the analysis of platinum-group elements according to the method described by Häkli et al. (1976). The results presented in Table 8 indicate low tenors of PGE in

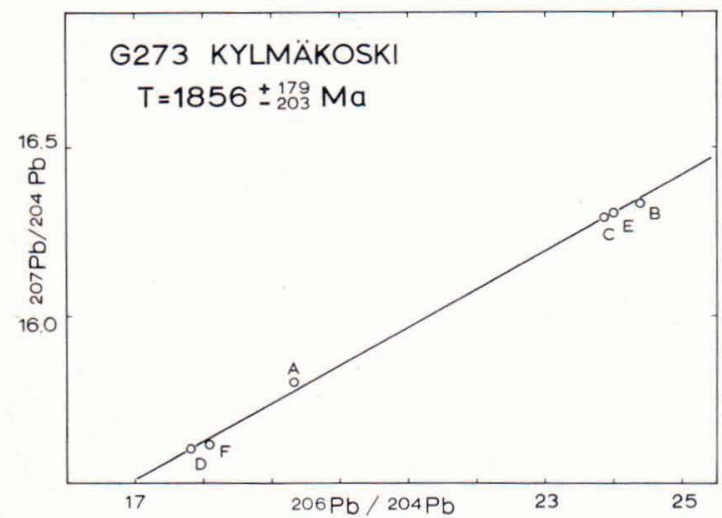

Fig. 14. Plot of lead isotope data for the analyses presented in Table 9 . disseminated and breccia ores and enrichment of PGE in the nickel-arsenide ore type, in which $\mathrm{Pd}$ is more abundant than Pt. In disseminated sulfides the reverse is often true.

\section{Dating}

A set of samples was collected for age determinations based on lead isotope data. Chalcopyrite fractions were separated by flotation and heavy liquids for extraction of trace amounts of lead. The isotope analyses were carried out by Dr. M. Vaasjoki and Dr. O. Kouvo at the geochronological laboratory at the Geological Survey of Finland.

The $\mathrm{Pb}-\mathrm{Pb}$ isotope data are given in $\mathrm{Ta}$ ble 9 . The least squares fitting line in the plot ${ }^{206} \mathrm{~Pb} /{ }^{204} / \mathrm{Pb}$ against ${ }^{207} \mathrm{~Pb} /{ }^{204} \mathrm{~Pb}$ defines an 
isochron that corresponds to an age of 1856 $(+179,-203) \mathrm{Ma}$ when the decay constant of Jaffey et al. (1971) is used (Fig. 14). The age is consistent with the lead-lead age of the Telkkälä deposit (Häkli et al., 1975) and slightly younger than the $\mathrm{U}$, Th- $\mathrm{Pb}$ ages of zircons from the Kotalahti deposit (Gaál, 1980) and Vammala (Häkli et al., 1979).

\section{Discussion}

The shape, setting and metamorphic alteration of the Kylmäkoski ultramafic body suggest that the body was already in its present environment when the wall rock gneisses were migmatized and folded. The palingenic neosome of the migmatite intersects and brecciates the ultramafic body as pegmatite veins. The zoned alteration selvages along the contacts of the pegmatites developed in peridotite, as a result of diffusion of alkalies, silica and aluminium, from pegmatites that darkened and are now composed mainly of plagioclase (cf. Papunen, 1970).

Although very small in size, the Kylmäkoski body is very similar to the Vammala deposit, which is the largest of the $\mathrm{Ni}-\mathrm{Cu}$ occurrences in the Pori-Kylmäkoski belt. The Kylmäkoski body is a subconformable wedge in migmatite and is intersected by quartz diorite. Its continuation to the north has not been established. Owing to similarities in structure and composition, the Kylmäkoski ultramafite and the Stormi ultramafic complex probably have a similar history of emplacement. According to Häkli et al. (1979), the magma of the Stormi ultramafite intruded into the argillaceous sediments at an early stage when the sediments were still only slightly consolidated. If the same is true for most of the sulfide-bearing ultramafites in the Pori-Kylmäkoski belt, their emplacement must be attributed to a long tensional geosuture, that permitted the injection of magma at the geosynclinal stage of the orogeny. This phase predates the regional metamorphism, folding and the youngest faulting that is now visible as lineaments in the topography (Tuominen et al., 1974).

The peculiar texture of the nodular and orbicular peridotite is explained as a result of rapid crystallization from supercooled magma. The lack of chromite in peridotite indicates low oxygen fugacity in the original ultramafic magma. Chromite could not crystallize as an early cumulus phase and, as shown by the pyroxenite analyses in Table 3 , the chromium in the magma was later incorporated in the pyroxenes.

In a mafic magma, chromite probably acts as a nucleus for crystallization, even for silicate minerals (Wager, 1959). Thus, the lack of chromite further contributed to the supercooling of the magma and the sudden rapid growth of olivine crystals as soon as the nuclei were formed. The magmatic origin of the orbicular texture, as suggested by $\mathrm{Mu}-$ tanen (1974), can well be applied here.

The skeletal crystallization of nodular peridotite is consistent with the hypothesis of the rapid injection of magma into a rather cool environment. The same type of orbicular peridotite was reported in the contact of the Vammala deposit by Häkli et al. (1979).

The sulfides were liquated before the crystallization of olivine nodules. This is demonstrated by the lack of sulfides in the interior of the olivine nodules. The olivine crystallized from the magma which through liquation was already depleted in sulfides. The nodules settled down together with the sulfides, which now occasionally form massive but minute layers. The massive sulfide layer that was visible in the open pit was not horizontal but tilted to the west, approximately parallel to the contact of the ultramafite with the wall rock. 
The small body underwent deformation, alteration and regional metamorphism, and hence the original basement can no longer be entablished.

Acknowledgements - Dr. T. A. Häkli in the Exploration Department of Outokumpu Oy provided the author with the analytical data; Dr. M. Vaasjoki in the Geochronological Laboratory at the Geological Survey of Finland performed the age determinations, Mrs. Gillian Häkli, B. A. corrected the English of the manuscript and Mrs. Rauha Turunen in Outokumpu Oy draw the figures. To all of them the author would like to express his sincere thanks.

\section{References:}

Eskola, P. (1963) The Precambrian of Finland. In K. Rankama (editor): The Precambrian, Vol. I, John Wiley \& Sons Inc., London, 145-263.

Evans, B. W. and Trommsdorff, V. (1974) On elongate olivine of metamorphic origin. Geology 2, $131-132$.

Gaál, G. (1980) Geological setting and intrusion tectonics of the Kotalahti nickel-copper deposit, Finland. Bull. Geol. Soc. Finland, 52, 101-128.

Häkli, T. A. (1970) Factor analysis of the sulphide phase in mafic-ultramafic rocks in Finland. Bull. Geol. Soc. Finland 42, 109-112.

- (1971) Silicate nickel and its applications to the exploration of nickel ores. Bull. Geol. Soc. Finland 43, 247-263.

- , Huhma, M., Viluksela, E. and Vuorinen, Y. (1975) A minor Ni-Cu deposit at Telkkälä, SEFinland. Bull. Geol. Soc. Finland 47, 55-70.

- , Hänninen, E., Vuorelainen, Y. and Papunen, $H$. (1976) Platinum-group minerals in the Hitura nickel deposit, Finland. Econ. Geol. 71, 12061213.

- , Vormisto, K. and Hänninen, E. (1979) Vammala, a nickel deposit in layered ultramafite, southwest Finland. Econ. Geol. 74, 1166-1182.

Jaffey, A. H., Flynn, K. F., Glendenin, L. E., Bentley, W. C. and Essling, A. M. (1971) Precission measurements of half lifes and specific activities of 235U and 238U. Phys. Rev. 4, 1889-1906.

Kahma, A. (1973) The main metalligenic features of Finland. Bull. Geol. Survey Finland 265, 29 p.

Matisto, A. (1976) Suomen geologinen kartta $1: 100000$, Kallioperäkartan selitykset, lehti 2114, Toijala. Summary: Precambrian rocks of the Toijala map-sheet area. Geological Survey of Finland, 26 pp.

Mutanen, T. (1974) Petrography and protoclastic structures of the orbiculite boulders from Sääkslahti, Toivakka, Finland and the magmatic genesis of orbiculites. Bull. Geol. Soc. Finland $46,53-74$.

Naldrett, A. J. (1973) Nickel sulphide deposits their classification and genesis with special emphasis on deposits of volcanic association. Can. Inst. Mining Met. Trans. 76, 183-201.

Papunen, H. (1970) Sulfide mineralogy of the Kotalahti and Hitura nickel-copper ores, Finland. Ann. Acad. Sci. Fenn. Ser. A III 109, 74 p.

- (1974) The sulfide mineral assemblages of some Finnish Ni-Cu deposits. Problems of Ore Deposition, IAGOD Symposium 4th, Varna, vol. 2, $311-319$.

- (1976) Outokumpu Oy:n Kylmäkosken kaivoksen geologiasta. Summary: On the geology of the Kylmäkoski mine. Vuoriteollisuus-Bergshanteringen 34/2, 119-123.

- Häkli, T. A. and Idman, H. (1979) Geological geochemical and mineralogical features of sulfide-bearing ultramafites in Finland. Canadian Mineral. 17, 217-232.

- and Mäkelä, M. (1980) Sulfar isotopes in Finnish nickel-copper occurrences. Bull. Geol. Soc Finland 52, 55-66.

Penttinen, U., Palosaari, V. and Siura, T. (1977) Selective dissolution and determination of sulphides in nickel ores by the bromine-methanol method. Bull. Geol. Soc. Finland 49, 7984.

Tuominen, H. V., Aarnisalo, J. and Söderholm, B. (1973) Tectonic patterns in the central Baltic Shield. Bull. Geol. Soc. Finland 45, 205-217.

Wager, L. R. (1959) Differing powers of crystal nucleation as factor producing diversity in layered intrusions. Geol. Mag. 96, 76-80.

- and Brown, G. M. (1968) Layered igneous rocks. Oliver and Boyd, Edinburgh. 588 p

Manuscript received, April 2, 1980 